\title{
Art and Reality
}

\section{in a Post-Modernistic Paradigm of Abram Tertz: "Life Situations" and "Art Situations"}

\author{
Gulnar K. Shomanova* \\ S. Toraigyrov Pavlodar State University \\ 60 Lomov Str., Pavlodar, 140000, Kazakhstan
}

Received 22.02.2016, received in revised form 14.04.2016, accepted 04.05.2016

The creative work of A. Tertz (A.D. Siniavskii) in the 60's developed the post-modernistic representation of the issue of art and attitude to reality, which was preceded by literary-and-critical works.

The article educes the peculiarities of a post-modernistic paradigm of "art and reality", and its impact on the genre strategy of Tertz. The origins of iterative citationality are reviewed in such books as " $A$ Voice from the Chorus", "Strolls with Pushkin" and "In the shadow of Gogol".

The subject of the article is the impact of "fantastic realism" of the writer on pieces of work dedicated to art. The duality of the hero, aesthetics of the scary and the horrible, the gothic, detective genre tactics, adventurous plots are analyzed as principles of "fantastic realism" or poetics of "schizodiscourse". The typology of a "small person" of the 60's is brought to light. The article reveals the influence of prison experience of Tertz on understanding and representation of art.

The author established the technique of creating secondary reality (parodying the concepts of poststructuralism); the peculiarity of author's mystification and methods of imitating high style are characterized. Also he identifies the relation between the idea of futility of art and standard poetics, which explains the domination of grotesque S. Toraigyrov Pavlodar State University

60 Lomov Str., Pavlodar, 140000, Kazakhstan physiologism.

The article studies the essence of duality in Tertz' poetics in the aspect of aberration and autobiographism, as well as the fragmentary nature of writing, the technique of arrangement as symbols of genre transformation, which is characterized by belonging to prison prose. Poetics of postmodernism with its receptive nature is analyzed in the context of a literary game.

Keywords: Abram Tertz, postmodernism, "fantastic realism”, “duality”, futility, schizo-discourse, prison prose, mystification, genre transformation.

DOI: 10.17516/1997-1370-2016-9-5-1239-1248.

Research area: philology.

\section{Introduction into the problem}

By the 60's Andrei D. Siniavskii (Abram Tertz) demonstrates poetics of schizo-discourse and phantasmagoria of artistic and contemplative feelings. In these circumstances, the central problem of the aesthetic and artistic thinking of the writer - art and attitude to reality -

(C) Siberian Federal University. All rights reserved

* Corresponding author E-mail address: gau.06@mail.ru 
is experiencing a new wave of postmodern interpretation.

Summing up the thoughts on art and his attitude to life, Abram Tertz admitted that he had a "strange feeling" and a "heretical thought" that "art is somewhere higher than reality and is more important than life... I mean art that sometimes falls down to the lowlands of life and tells about it more than it knows of itself. Yet it is independent of life. $<\ldots>$ Art is freer and stronger than life and the authors who create these things. In this sense, it is actually higher than reality" (Tertz, 1978, 62).

The attitude to art and analysis of the relationship with reality gave birth to literarycritical works by A.D. Siniavskii "Literaturnyi protsess v Rossii”" (“Literary process in Russia") (1974), "Iskusstvo i deistvitel'nost”" (“Art and Reality") (1978), "Dissidentstvo kak lichnyi opyt" (“Dissidence as a personal experience") (1989), "Osnovy sovetskoi tsivilizatsii" ("Fundamentals of Soviet civilization") (1989), "Ia i oni: O krainikh formakh obshcheniia v usloviiakh odinochestva" ("I" and "They": On the extreme forms of communication in terms of solitude") (1991), etc. They were preceded by a theoretical justification of art that emanates from denial of social realism in a treatise "Chto takoe sotsrealizm?" ("What is socialist realism?") (1957). The same problem brought to life in different years other stories by Tertz: "Ty i Ia" ("You and I") (1959), "Grafomany (Iz rasskazov o moei zhizni)" ("Graphomaniacs (From stories about my life)") (1959), "Golos iz khora" (“A Voice from the Chorus”) (1966-1971).

\section{Conceptological research base}

Postmodernism of Tertz in the aspect of the problem of art and the attitude to reality has become the subject of research works of a Japanese scholar Iu. Nakano. Thus, the novelty of the solution to the problem of art and reality is, according to the scientist, in the spirit of legal persecution of art, in a paradoxical formula, according to which "art is a crime, and a writer is a criminal" (Nakano, 2007, 6): "The author is trying to create an impression for the readers as if they read a manuscript, draft, segmentary notes" (Nakano, 2007, 7). In our opinion, the fragmentarity of writing, editing technique conditioned by belonging to a camp prose, received the shape of genre transformation here.

"Fragmentarity" as a characteristic feature of Tertz texts gives rise to opposite assessments of critics and researchers. Thus, A. Genis (1999, 5) considers "fragmentarity" as a creatively productive principle. R. Gul $(1976,6)$ gave sharply negative comments on "Strolls with Pushkin" and described the work as "a rough draft that is compositionally and stylistically incomplete." From the point of view of B. Groys $(2002,7)$, I. Skoropanova (2004, 8), M. Epstein (2005, 9), fragmentarity is evaluated positively as a striking sign of postmodernism.

\section{Problem statement}

Relevance of this article is due to a number of circumstances. Firstly, this and other works of the author of this article settles down belonging of works by Tertz to postmodern literature of the first wave (Shomanova, 2015a, 149-160), (Shomanova, 2015b). Secondly, art and reality as a postmodernist paradigm that determined the genre strategy of Tertz do not become the subject of the research. Thirdly, yet no one has paid attention to the origins of iterative citationality of Tertz, which stretched from the book "A Voice from the Chorus" to the poetics of the book "Strolls with Pushkin" and "In the Shadow of Gogol". This approach conditioned the objective of this article that is to see the effect of the writer's "fantastic realism" on the works devoted to art.

Application of the immanent, formal and hermeneutic methods helped to reveal the specifics of postmodernist interpretation of art 
and attitude to reality as sources of poetics of schizo-discourse in works by Abram Tertz in the 60's.

\section{Discussion}

Regarding the story "You and I" the article by P.F. Podkovyrkin (online) is of great interest. The researcher noted a reminiscential, literary series ("St. Petersburg Stories" by Nikolai Gogol, "The lame devil" by Lesage, "Buridan's ass" by W. Saroian) and a figurative series ("The Last Supper" by S. Dali).

Yet, the postmodernist core of the story "You and I" is, in our opinion, in a phantasmagoric plot, fantastic invasion of a writer as the allegory of the Creator "interfering" in the current course of events, allegorically embodied in the author's will and a hero avoiding (escaping) from it. We can associate it with the "Obstanovochka" by Sasha Chernyi, with its avant-garde poetics with emphasis on life, routine, stultifying course of events. So it is possible to reveal methods for creating secondary reality in Tertz works.

A Biblical epigraph to the concept of existential loneliness and uncertainty of the prophet Jacob: "And Jacob was left alone. And there wrestled a man with him until the breaking of the day..." - reflects a conflict of the author and the hero as an eternal law of art and an ontological chasm between art and reality. Hence a "strange shade" of a mystical story of the hero who bears the name of Nikolai V. Gogol, the famous hoaxer, with his intense interest in the fate and death.

A poststructuralist concept of the author's death transformed into the hero's death gives a mystery shade to the story. Genre transformation is based on the monotonous repetition of events and parodic reducing of the sacred nature of repeats: "It was snowing. A fat woman was brushing her teeth. Another fat woman was scaling fish. The third one was eating meat. Two engineers were playing Chopin four-hands. In maternity wards, four hundred women were giving birth to children simultaneously.

An old woman was dying.

$A$ dime rolled under the bed. Father said with a laugh: "Oh, Kolia, Kolia." Nikolai ran at jogtrot in the frost. A brunette was having a bit of a wash in a basin before the meeting. A brownhaired was putting on her pants. Five kilometres from there - her lover, for some reason, named Nikolai as well, was creeping around the blooddrenched apartment with a suitcase in his hand.

The old woman was dying - not this one, another one"1.

The course of events, mundane and terrible in its ordinariness, when an exceptional phenomenon of death, the existential is inscribed in a household series together with "basin" and "pants", and "blood" taboos a crime of death, organizes framing of the work. At the end of the work the monotony of the phrase: "Everything was as usual. It was snowing and it was the same time of the day" encircles the images of two engineers, Lobzikov and Polianskii, who keep playing Chopin; four hundred women giving birth to four hundred babies per minute; a brownhaired putting on her pants; a brunette getting ready for a meeting" has only one difference: "Nikolai's body was lying in a locked room. Lida, like a security, was walking around under the windows."

Duality of the hero, splitting of personalities into namesakes, when the hero and the author merge into one entity, bear the same name, but the author cannot prevent the death of the hero, reveal the nature of mystification of the author, his prank. According to the canons of mystical literature he created and exposed the imaginary aesthetics of the terrible and the horrible, the gothic in the spirit of ballad poetics. Detective genre tactics justifies the adventure plot and cynical attitude towards death, deprivation of its intimate properties. 
The ending in a false-pretentious, pseudoclassical tone: "You left, and I stayed. I do not regret your death. I'm sorry, I cannot forget you"reveals the provocative nature of postmodernism. Expectation from a love story given by the name of "You and I" contains a hint at the metaphysical nature of man's relationship with the cosmos.

Flash fiction of Tertz is presented by the work "Graphomaniacs (From the stories of my life)." Postmodernist aesthetics continues the theme started in "Kvartiranty" ("The Tenants") poetics of schizo-discourse. Graphomania is not in the typical sense of a pen disease, but a disease of the spirit caused by the social status of society, and has a tragic and grotesque parody nature simultaneously.

The beginning of the story does not seem to leave any illusions: "We need to remember to use: "In the air one could feel a breath of the approaching storm." The irony about the national disease of the spirit clothed in the grace of the formula of "people's propensity to belles-lettres", determines a cause of the disease: "Do you know what we owe? - Censorship! She, our dear mother, caressed us all."

"The state itself" plays the role of a benefactor, which reveals the social role of art. Division of the fraternity of writers into geniuses and graphomaniacs acquires schizophrenic dedication of renunciation of a friend who was loyal until recently. Pronounced ugliness of the hero's wife Zinaida as an obstacle to creativity, hindrance to art is described both comically and cynically: “...it would be a way out if Zinaida cheated on me with somebody and that somebody would marry her. But who would marry her - an ugly woman in torn stockings, with a six year old child? She will hang around my neck until death. If she died, the room would get quiet, roomy and I could calmly write in the evenings. And let Pavlik live, he is a quiet and polite boy and will not bother me. When he grows up, he will be entrusted my entire archive or a museum, as is usually done with children of famous writers."

A cynical need to justify cowardice and inadaptability to life requires an intellectual explanation. And it is found. Glory as an eternal engine of progress and culture motivates the hero for testing through adversity "on the road to glory", but not through everyday life and family.

In the story Tertz developed a new, modern variation of a "little man". The reminiscential nature of the story abounds with longueurs, syllogisms, sophistical arguments about the literary work. "The writer talks with friends, rambles in drafts, repeats hackneyed phrases, stumbles, talks nonsense. And suddenly, he blurts out! He blurts out something that got into his head, turned up on the tip of his tongue. And it is most important to babble out an unexpected word, in which the whole world will finally see, as Galkin loved to pompously say, its most loyal, most accurate synonym." The discovery of a graphomaniac: "The more I work, the better I understand: the best that I've written does not belong to me and, darn it, seems to be written not by me" is called the effect of "self-removal": "This is what we work tirelessly for, write tons of paper out with hope to remove ourselves, overpower ourselves, give access to the thoughts out of the air."

The object of the postmodernist irony requires imitation of high style and parody of supposedly theoretical justification. Galkin drew an analogy between a graphomaniac and a genius, "called graphomania bedrock, the beginning of beginning and called it marshy soil that is the origin of the purest springs of poetry." Parody of proletarian classics: "Those who were nothing, said Galkin, will become everything" was a kind of a civil act, since it was an encroachment on a super-text of communism.

Forming a line out of the Gogol's troikabird: "Oh, Rus! Where are you racing to?", 
Pushkin's "Rosy dawn broke out in the East", a trilogy by Fedin, an example of social realistic canon (yet Fedin "had neither intellect, nor the talent or knowledge of the subject he writes about") creates an element of intertextuality as the emergence of the basic concept of Russian literary postmodernism.

Transformation of a hyperbole into grotesque creates the illusion of complete happiness of graphomaniacs and victory of art over life realizing the Leninist principle of popular art: "It was late in the evening - a favourite time for graphomaniacs, and in every hole I knew someone was writing something. It seemed that the city teems with writers and they all, young and old, were scratching the paper with ball pens!"

Madness of the "the most evil, inveterate graphomaniacs" draws cynical and cruel association in the hero. Rage towards classics who occupied the field of literature and did not leave room for the graphomaniac descendants not only develops in Tertz the idea of futility of art, death in standard poetics, but also is implemented in cynical ways of grotesque physiologism, narrow-minded morality that is destructive from the standpoint of ethics. "The classics that's who I hate more than everything! They occupied job vacancies even before I was born, and I had to compete with them without having a hundredth share of their phony authority. - Read Chekhov, read Chekhov - I have been told all my life tactlessly hinting that Chekhov wrote better than me... And how on earth I could deal with them when nails of Leo Tolstoy cut a thousand years ago and collected by a long-sighted Graf are sacredly stored in a special bag in Yasnaya Polyana?! And in Yalta, they say, dried spittle of Chekhov is being reserved in special bags. Yes! Authentic spittle of Anton Chekhov who is said to have suffered from blood spitting and even died from tuberculosis, which, of course, is an exaggeration."
The following passage draws in the cultural consciousness the associations with the philistines of Russian literature in the 20-30's in the spirit of P. Romanov, Ilf-Petrov, M. Zoshchenko. "But to be honest: did Tolstoy and Chekhov really write so well? That's right! I wish I could take this Chekhov by his tuberculosis beard and poke his nose in his consumptive spittle that, unfortunately, has already dried up: - Do not write, graphomaniac! Do not write! Do not spoil the paper!"

Schizo-discourse is conditioned by a metaphor as a technique of transformation of consciousness: "Suddenly it seemed to me that it was not me who was walking down the street, but someone's fingers are leading me like a pencil on paper. I walked at fine uneven handwriting; I was in a hurry trying to catch up with hand movement that wrote on the asphalt these deserted streets, houses with lights on and myself, all of my long unsuccessful life."

The novelty of the interpretation of duality, origins of which go back to the stories by Tertz in the 50's "V tsirke" ("At the Circus"), "Sud idet" ("The Trial Begins"), "Kvartiranty" ("The Tenants") is in a tragic monologue, tragic because bad luck, futility, creative frustration, emptiness, death of art became synonymous concepts and a diagnosis of society. Even the thaw did not squeeze out a Chekhov slave drop by drop and has become a source of spiritual anabiosis.

The novelty of the interpretation of duality lies in the foolishness of graphomania as an object of apprehension and enlightenment of the hero: “Hey, you, graphomaniac! Quit your job! Everything that you write is no good. Your writing is mediocre. It is impossible to read you..."

The prophetic tone of narration from the first person in the ending took on the character of sentence, practically like in N. Chernyshevskii, with his theory of literature as a textbook of life justified in his Master's thesis "On the Aesthetic Relations of Art to Reality". To show - to 
explain - to pass a sentence on reality - such a formula of art (literature as a kind of the textbook of life) tracing to the Master's thesis by N. Chernyshevskii symbolically determined the ending.

The ending is an independent text. This title "Graphomaniacs" emphasizing autobiographism as a way to create factual, psychological, literary authenticity of narration and typification, and the subtitle in brackets "From the stories of my life" conveys unspeakable dramaturgy of the ending.

"Golos iz khora"("A Voice from the Chorus") was written in a camp (1966-1971). It was printed in 1973 in London. The genre is the same as "Mysli vrasplokh" ("Thoughts Unaware"). Both books reproduce the genre of "Opavshie list'ia" ("Fallen Leaves") by V. Rozanov.

"The Chorus" of camp voices: "There were six killer wards" - the existential work by Tertz. The book contains the author's thoughts on God and the meaning of life, art, death, love, history, Russian nature. If all other works of Abram Tertz are a kind of super-text with one plot fate of an artist defending his creative freedom, independence of art, then in this work human psychology in captivity received extremely heightened reactions, physical sensations and a sense of touch.

The unknown author writes about the prison - camp - captivity like a new type of communication and new representation of personality through language consciousness: "In a prison, says Siniavskii, "the need for communication that transcends the ordinary everyday communication extremely increases", breakage of communication leads to awakening of language increased in its communicative significance, precisely because of the increased isolation" from the world. In this regard, the camp only pushes to the limit a situation of extreme loneliness and the need for understanding and communication, which is happening to the author outside the prison who feels "strongly apart and cautious in relation to society".

However, the conclusion, according to Siniavskii, strengthens the desire to refuse from the imposed regime of the odious form of communication, turn to "another language" or even "get out of the language", and if "it is a man of art, - stimulates turning to the extreme measures of influence - epatage, grotesque, absurd, fiction, all kinds of extravagance, which can be characterized "as a form of the exaggeratedly expressive, aggressive and at the same time exaggeratedly communicative speech." This acknowledgment of Siniavskii-Tertz not only contains the prerequisites of origin of his poetics, but also the experienced physically liminal, borderline states of mind. Hence the schizodiscourse and phantasmagoria of his artistic and contemplative perception strengthening in the 60's.

Prison conditions maximally actualize the psychological need to "reach some life boundaries, and even cross these boundaries in order to create something", which is inherent in the process of creation. "Is it due to the eternal art attempts to jump out of everyday life, the state, the mundane world and art itself? What if the main goal of the artist is to go outside the line of style, genre and his own life?" Until now the researchers have not paid attention to the origin of iterative citationality, which will determine poetics of "Strolls with Pushkin" and "In the Shadow of Gogol".

A special feeling of a person, especially an artist, in captivity opens for Tertz a formula of art: "I suddenly became convinced of what role plays the living nature for the artist, since it is not simply an object of the image, but a metaphor and a breath of his inner world."

"The right of the increased figurativeness" hones the writing vigilance. For example, the contrast of "urban", "decent faces" with obvious 
"indistinctness": "The contours are wiped out, effaced with uncertain fat - at the presence of the character, costume and status", faces of old age or in prison: "there where nothing is left, suffering cut through the faces, and they pop out at the viewer: a nose sticks out like a spear, the eyes cast pearls, and a mouth is grinned, in the absence of a standard smile, in undisguised greed to be. A face bears honour of the last representation."

Preservation of human emotions as a sign of self-preservation illustrates the paradoxical examples. But their paradoxicality is not so obvious. Here paralogic that is functioning as logic is true. "An old man is reading a reference book on elementary mathematics. A son sent it to the neighbour. He does not understand anything about it. Some sines and cosines. But he is reading it anyway. From cover to cover: my son sent it!" Here is a remark of the author enclosed in brackets: "This is in the soul of things. If you sent a book on geometry to someone here, I would probably take a look at it. The contact with a face is more important than contents of a book."

Poetics of postmodernism has already found a receptive nature at the stage of formation. A play with the "outside word" has acquired a scandalous cynical shade reflecting transformation of the norm in such passages as "If the Lord asks what was the worst-best thing happened in my life, for the worst I will choose four episodes. And for the best I will say, anasha." Or the expression of another truth. "That is what destroys us - we think that we will get away (with crimes)." However, the "outside word" of Tertz is a synthesis in duality of the high and the low, the popular-folklore and the official. A nostalgic, romantic secret and a prayer may deprive him of his monologue about the secret of art of cynicism and contain only the confessional beginning, the secret of belonging. "When people ask me what art is, I start to laugh quietly in surprise at their exorbitance and inability to express their content that is constantly changing and is attracting as light. Lord, I have spent all my life only to get to the core of its meaning, and in the end I cannot do anything and do not know how to say it. I say "possibly", "probably”, "hopefully”, "whether it is not this or that" and immediately get lost in unsolvedness of the problem. So, it kills me when certain aestheticians give definitions as if they know exactly what it is (as if there was someone who could know for sure, as if it is possible to find out!). Art is always a more or less improvised prayer. Try to catch the smoke."

Synthesis of the genre is to create authentic imitation of separate voices. Hence the phrases and diary fragments: "All the time it seems that there is some book that should be read by all means, it is just that I still cannot find which one..?", "Why do people feel satisfaction?"

The ironic comparison of personal history with ballads by Zhukovskii, his "Lenore" is at the other side of thieves' compassionate songs with cynicism of an educated man. The comparison of "life situation" and "art situation" is based on the time categories of the past with "flickering hope" and "timidity of the shamelessly uttered first word: Beloved!"

The laws of art discovered in captivity are different. This alternative field of literature is paradoxical and gives to the familiar an unexpectedly new sound, auditive in particular. "Here is all the strength in the plural. Illiteracy and inaccuracy of speech, deviations into jargon, dialect are shifting a word in the field of an auditory sense. Sometimes, a wastrel tale sounds realistic, despite the cliché of an evil stepmother or a strange father."

The understanding and interpretation of art are also influenced by the prison experience. Hence the definitions from a thieves-talk: "Art is like a woman - it is spinning around in front of a mirror and is looking at itself while waiting guests", inclusion of a thieves song with 
comments reflecting its creation according to the canons of art taking into account prosodic norms and requirements. For example, "a "perfectly innocent" rhyme would probably be more correct by the sense of exposition". Or: "After all "he also bounced her into a tango" would be more correct. Boston seemed smarter and knocked the rhyme out. The epithet "superstitious" is beautiful and has no meaning other than decorative." The analysis and the reflective nature of the text created on the basis of the unconscious, from the academic point of view, aesthetics are highly postmodernistic.

"The last two lines - to a high standard" implement the evaluation criterial system. "So we have paid a score with the prosecutor!" - a personal voice together with the chorus sounds like the expression of a common destiny.

Indication of artificiality of the story: "In life such collision when a prosecutor judges his own daughter is completely impossible. But it is artistically credible and decisive. A similar turn can be observed in the ending of "Ninety-Three" by Hugo, where he reflects in a remarque nature of comments and references a receptive strategy and a new real experience of a camper, thus mobilizing a social aspect of duality. A summary "For the sake of this tear, the whole song was written" corresponds to the composition of a review of any work, the criteria of which are the laws of art and artistic logic. The jokingly-parodic comparison of a queue for lunch to a bookshelf combination of different languages from different cultures removes the border between art and reality. "And suddenly, among the equally shabby volumes, you find a feeble story..." - it is not imitation of colloquialism and vulgarism, but a synthesis, dialectical logic of unity and struggle of opposites.

The eclecticism of the "outside word" implements reliability of the medical report when schizo-discourse of postmodernism can appeal to the terminology: "There is social undermaintenance and pathological development of personality" (from the psychiatric examination)." Discussions about books and literature are a necessary part of all the works by Tertz. "A Voice of the Chorus" is not an exception in this regard.

\section{Conclusion}

Thus, the concept of "fantastic realism" keeps the focus on phantasmagoria and has revealed the evolution of the artistic solutions. Firstly, the Tertz concept, the concept of "fantastic realism", complicated the phantasmagoric plot by a picture of everyday life, which showed the effect of parody of concepts of post-structuralism as a technique of creating secondary reality. Therefore, the post-structuralist concept of death of the author was transformed into the hero's death. Secondly, the novelty of mystification of the author lies not only in the aesthetics of the terrible, the horrible, and the gothic in the spirit of ballad poetics, but also in the detective genre tactics, with an adventurous plot and cynical attitude toward death. Thirdly, the provocative essence of postmodernism with poetics of schizo-discourse, a tragic and grotesque parody nature, demanded from the writer the imitation of high style and a parody of imaginary theoretical justification. Fourthly, the intertextuality as the emergence of the main concept of Russian literary postmodernism substantiated the idea of the futility of art, death in standard poetics. Hence the predominance of the grotesque physiologism. Creative powerlessness, emptiness, death of art became synonymous concepts and a diagnosis of society, a sign of spiritual anabiosis. The novelty of the interpretation of duality is in the foolishness and autobiographism as ways to create factual, psychological, literary authenticity of narration and typification. Fifthly, fragmentarity of writing, editing technique conditioned by belonging to 
the camp prose received here the shape of genre transformation. Sixthly, poetics of postmodernism with its receptive nature has given a "fun" literary game in the 50's a scandalous cynical tone.

Tertz A. (Andrei Siniavskii). Sobraniye sochinenii v 2-h tomakh, tom I (Collection of writings in 2 volumes, Volume 1). Moscow, Publishing House SP “Start”, 1992, available at: http://webreading.ru/prose_/prose_su_classics/abram-tercandrey-donatovich-sinyavskiy-rasskazi.html\#ixzz2em7FvNLO.

\section{References}

Epshtein, M. (2005). Mezhdu ekzistentsialismom i postmodernizmom [Between existentialism and postmodernism]. Andrei Sinayvskii. Postmodern v russkoi literature. [Post-modern in Russian Literature]. Moscow, Vysshaia shkola, 328-369.

Genis, A. (1999). Ivan Petrovich umer. Stat'i i rassledovaniia [Ivan Petrovich has passed away. Articles and investigations]. Moscow, NLO, 32-38.

Groys, B. (2002). A philosopher after the end of the story. Escaping context [Philosof posle kontsa istorii Uskol'zaiushii context]. Materialy konferentsii Russkaia philosofiia $v$ XX veke. [Conference materials, Russian Philosophy in the 20 $0^{\text {th }}$ century]. Bremen, June 25-27, 1998. Ad Marginem, 147160.

Gul, R. (1976). Progulki khama s Pushkinym [Walks of a boor with Pushkin], In Novyi zhurnal (New Journal), 124, New York.

Nakano, Yu. (2007). Tvorcheskaia biographiia Andreia Siniavskogo skvoz' prizmu literaturnogo amplua Abrama Tertsa [Creative biography of Andrei Siniavskii through the prism of the literary character of Abraham Tertz]. Avtorefer. diss. kand. philol. nauk. [PhD thesis] Moscow: MSU, $21 \mathrm{p}$.

Podkovyrkin, P.F. Andrei Siniavskii i "Abram Tertz" [Andrei Siniavskii and Abram Tertz], available at: http://ppf.asf.ru/terz.html (Accessed September 17, 2013)

Shomanova, G. (2015b). "Veseloe izdevatel'stvo" nad sotsrealizmom" v rasskazakh Abrama Tertsa ["Funny mockery of social realism" in stories by Abram Tertz]. Philologo-kommunikativnye issledovaniia 2015. [Philological-and-communicative studies 2015] Barnaul, Izdatel'stvo Altaiskogo gosudarstvennogo universiteta (Publishing house of Altai State University).

Shomanova, G. (2015a). "El realismo fantástico" de Abram Tertz: modificación, estructura, síntesis de género. Guadernos de Rusistica Espanola. Granada, 11, 149-160.

Skoropanova, I. (2004). Russkaia postmodernistskaia literature [Russian Post-Modernistic literature]. Moscow, Flinta, 608 p.

Tertz, A. (1978). Iskusstvo i deistvitel'nost' [Art and reality]. In Sintaksis (Syntax), 2, 48-62.

Tertz, A. (Andrei Siniavskii) (1992). Sobranie sochineniiv 2-kh tomakh, tom I [Collection of writings in 2 volumes, Volume 1]. Moscow, Publishing House SP "Start", available at: http://webreading.ru/ prose_prose_su_classics/abram-terc-andrey-donatovich-sinyavskiy-rasskazi.html\#ixzz2em7FvNLO (Accessed December 19, 2013). 


\title{
Искусство и действительность
}

\section{в постмодернистской парадигме Абрама Терца: «Ситуации жизни» и «Ситуации искусства»}

\author{
Г.К. Шоманова \\ Павлодарский государственный университет, \\ им. С. Торайгырова \\ Казахстан, 140000, Павлодар, ул. Ломова, 60
}

В творчестве А. Терияа (А.Д. Синявского) 60-х годов развивалась постмодернистское представление вопроса искусства $и$ отношения $\kappa$ действительности, которому предшествовали литературно-критические работы.

В статье выявляются особенности постмодернистской парадигмы «искусство и реальность», а также ее влияние на жанровую стратегию Териа. Рассматриваются истоки сквозной иитатности как в книге «Голос из хора», так и в поэтике книг «Прогулки с Пушкиным» и «В тени Гоголя».

Предметом статьи является влияние «фантастического реализма» писателя на произведения, посвященные искусству. Анализируется двойственность героя, эстетика страшного и ужасного, готического, жанровая тактика, авантюрные сюжеты как основные принципы «фантастического реализма» или поэтика «шизодискурса». Освещается типология «маленького человека» 60-х годов. Демонстрируется влияние тюремного опыта Териа на понимание и представление искусства.

Автор установил методику создания вторичной реальности (пародируя концепиии постструктурализма). В статье характеризуется особенность мистификаиии автора и методы имитачионного высокого стиля. Выявляется соотношение между идеей бесплодности художественной и нормативной поэтики, что объясняет доминирование гротескной физиологии.

Суть двойственности в поэтике Териа рассматривается в аспекте аберрачии $и$ автобиографизма. Как символь жанровой трансформачии, фрагментарный характер письма, методика систематизачии характеризуются принадлежностью $к$ тюремной прозе. Поэтика постмодернизма с ее рецептивным характером анализируется в контексте литературной игры.

Ключевые слова: Абрам Тери, постмодернизм, фантастический реализм, двойственность, бесплодие, шизодискурс, тюремная проза, мистификаиия, жанровая трансформация.

Научная специальность: 10.00.00 - филологические науки. 